\title{
The Karst of the Transvaal (South Africa)
}

by

\author{
J. MARTINI and I. KAVALIERIS*
}

\section{INTRODUCTION}

The karst of the Transvaal has long attracted attention from South African geologists because of its implications in Engineering Geology, in Hydrology and to a lesser extent in Archaeology. Compared with the classic karst areas of Europe and America, the karst of the Transvaal is very different and perhaps unique. This is due to the peculiar composition of the rock involved; a siliceous iron and manganese-rich dolomite and probably also to climatic history.

\section{GEOLOGIC SETTING}

The only inportant formation to be affected by a karst process in the Transvaal is the Malmani Dolomite Formation of Precambrian age (about 2200 m.y.) which covers approximately $14.000 \mathrm{~km}^{2}$ or $5 \%$ of the Transvaal (Fig. 1). It consists of a sequence of well-indurated dolomite, generally stromatolitic and rich in chert layers and nodules. Limestone is very subordinate and is present only in certain areas mostly at the top of the Formation. The dolomite is characterized by a high content in Mn \& Fe which confers a dark-grey colour to the outcrops. Its thickness varies from $200 \mathrm{~m}$ to $1800 \mathrm{~m}$, but is generally of the order of $1500 \mathrm{~m}$.

Structurally the Malmani Dolomite Formation is part of the Bushveld basin and the Potchefstroom syncline and generally exhibits low to moderate dips. Strong folding and faulting are uncommon. Thousands of dykes of various sizes and ages intrude it everywhere.

\footnotetext{
* Geological Survey, Private bag X112, Pretoria, Rep. of South Africa.
} 


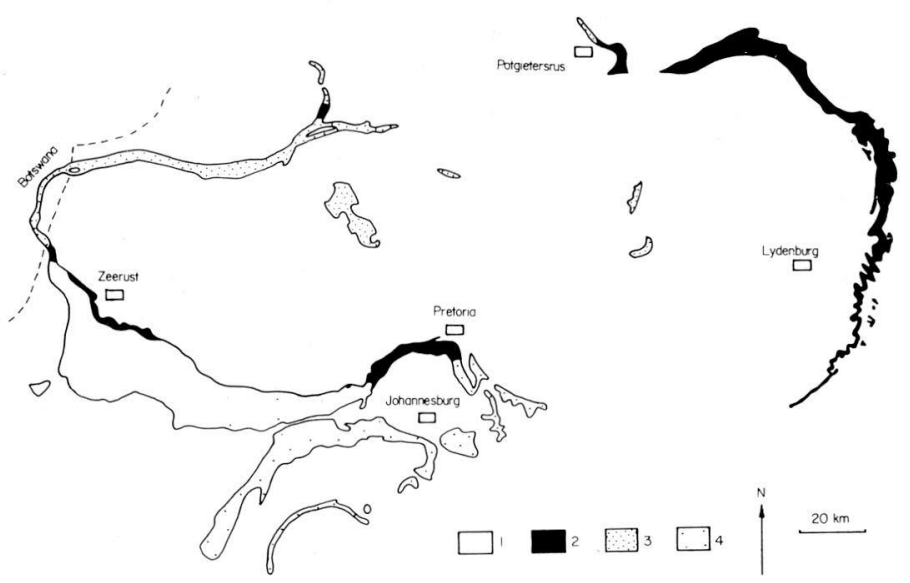

Fig. 1. Distribution of the Dolomite and morphologic types: (1) Plateau type, (2) Escarpment type, (3) Bushveld type, (4) Vaal River type.

\section{CLIMATE AND VEGETATION}

Over the karst area, the climate varies from warm temperate on the Highveld (Southern Transvaal) to sub-tropical in the Bushveld and in the Eastern Transvaal, with rainy summers and dry winters. Rainfall varies from more than $2000 \mathrm{~mm}$ in the Eastern Transvaal, near Graskop, to about $500 \mathrm{~mm}$ in the far Western Transvaal. Nevertheless in most of the dolomitic area rainfall is between $600 \mathrm{~mm}$ and $1000 \mathrm{~mm}$ (Weather Bureau, 1952). The vegetation cover is mostly of savannah park-land type. Some thick natural forests occur in very restricted areas in the Eastern Transvaal.

\section{KARST PERIODS}

The Dolomite has undergone at least four periods of karstification during its 2200 million year old history. These correspond stratigraphically to major recorded breaks in deposition, such as at present (Tertiary to Recent) when the Dolomite is exposed to pros. ad weathering. The four periods are:

1. Pre-Pretoria Group Karst Period

2. Pre-Waterberg Karst Period

3. Pre-Karoo Karst Period

4. Tertiary to Recent Karst Period

Although erosion during successive periods has progressively led to the removal of the earliest traces of karst over the greater part of the Dolomite sequence, there is evidence of a fossil karst, perhaps the oldest in the world, preserved in the Transvaal. 


\section{Pre-Pretoria Group Period}

The Pretoria Group which was deposited before the intrusion of the Bushveld Complex (1950 m.y.) overlies the Dolomite disconformably (Button, 1973). Evidence for an intensive and prolonged period of karstification before the deposition of the Pretoria Group is widely represented by the "Giant Chert", a chert breccia with a dark siliceous matrix, representing dissolution residuals. This formation developed on the top of the carbonate sequence is variable in thickness as well as lithologically.

Karst features still preserved that developed during this period include paleosinkholes filled with siliceous residuals, filled cave passages, collapsed chambers and breccia bodies sometimes mineralized with fluorspar, lead and zinc (Martini, 1975). These features are particularly well developed south of Zeerust in the Western Transvaal. The residual material is rich in carbon, probably due to a karst development in an atmosphere poorer in oxygen than at present.

\section{Pre-Waterberg Period}

Sandstone of the Waterberg Group (about 1900 to 1500 m.y.) disconformably overlies the Malmani Dolomite in several places in the Transvaal. Dissolution cavities in dolomite, filled with red sandstone, have been observed close to Lobatsi in Botswana, near the Transvaal border (personal communication from Mr. P. T. Wilson, Geological Survey).

\section{Pre-Karoo Period}

Prior to the deposition of the Dwyka tillite (Upper Carboniferous-Lower Permian), the Dolomite was subjected to erosion for a very long period, perhaps of the order of 1000 m.y. Paleosinkholes filled with chert breccia, kaolinitic clay, and carbonaceous sediments have been observed in many places, but mainly to the south of Pretoria and on the Far West Rand. The "bleached" character of varve-like iron- poor sediments filling pre-Karoo caves suggests a karst development under a cold climate, as may be expected from the associated glacial deposits.

Thick layers of coal (several tens of meters) occur in Karoo pockets resting on the Malmani Dolomite of the Far West Rand. They thin and peter out laterally very rapidly and testify to organic sedimentation contemporaneous with the karst subsidence (personal communication of W.M. Manaczynski, Geological Survey). It is likely that these depressions developed in a very mature stage, on a surface close to sea level.

Presumably this pre-Karoo Period may be subdivided into a pre-Dwyka tillite periode, which was interrupted by the development of the ice-shield, and a post-Dwyka tillite period probably short in time, which was terminated by the onset of Ecca sedimentation.

\section{Tertiary to Recent Period}

Epeirogenesis commencing probably during Late Mesozoic elevated much of South Africa and led to periods of erosion, followed by further uplift, to expose the underlying rocks, including the Malmani Dolomite. King (1962) proposed five major erosion surfaces related to episodic uplift. The oldest is the Gondwana (pre-Cretaceous or Jurassic), now largely confined to the Lesotho Highlands, and the youngest is the Quaternary, developed in the Low Veld. Of the other surfaces, the African is the most extensive and most evenly planed (King, 1962).

By early Tertiary time it is conjectured that sufficient Karoo had been removed to allow the evolution of a karst landscape over large parts of the Transvaal. This is the "present day" period and the only one that will be considered here in detail.

\section{MORPHOLOGICAL TYPES}

Four types of morphology can be distinguished on the Dolomite (Fig. 1 and 2).

\section{Plateau Type}

Between Krugersdorp and the Botswana border the karst area forms a flat plateau marking approximatelv the watershed between the Orange and Limpopo basins, with an average elevation 
of about $1500 \mathrm{~m}$. The Dolomite is frequently concealed under a thick blanket of residual material. This surface corresponds to the "African erosion surface" of King (Marker and Moon, 1969). with a possible age suggested by these authors of Late Cretaceous to mid-Cainozoic. It is interesting to note that this dolomite plateau also approximately coincides with the pre-Karoo surface, as isolated patches of Karoo rocks are scattered widely on the Dolomite from Pretoria to Lichtenburg. Consequently it is likely that this plateau was resurrected after removal of Karoo rocks by the African cycle. This is the only area in the Transvaal where a large-scale karst morphology is developed. This morphology is easily detectable on the 1:50.000 topographical map.
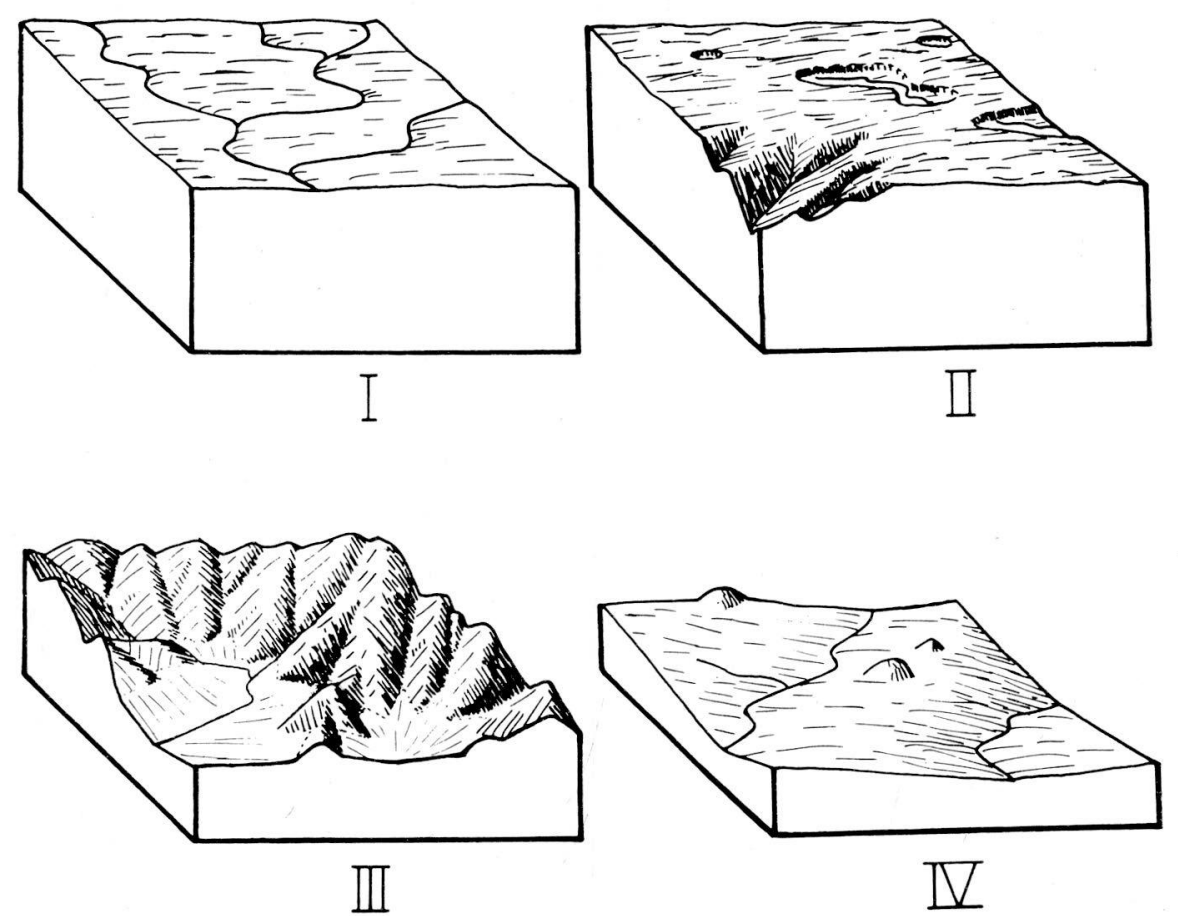

Fig. 2. Morphologic types: I. Mature type (virtually not present today), II. Plateau type, III. Escarpment type, IV. Bushveld type.

Only a few surface streams occur. Dissolution sinkholes and larger depressions of polje type are present. The latter are relatively well developed in the Western Transvaal near Ottoshoop, where they consist of large depressions 10 to $30 \mathrm{~m}$ lower than the plateau with flat, now cultivated, floors containing a fill of clay, sand, and sometimes calcrete and peat (Fig 3 and 4). These small plains are limited and surrounded by runiform and dislocated low bluffs of dolomite. The streams observed in the poljes may be generated by springs located in the depressions or by shallow valleys entering them. Swallow-holes seem to be represented by shallow depressions at the edges of the poljes (Fig. 4). These absorption points are choked by alluvials and they very seldom lead to water caves as is the case in the classic poljes of Yugoslavia. Only a few dry caves are located in the dolomite bluffs, not far above the watertable. During very rainy periods, and for a short time after, the poljes may be flooded by the rising of the watertable. The natural hydrology of the poljes has 
been altered by human activity as the water is everywhere tapped at the springs and diverted into irrigation furrows.

In the Ottoshoop area (Fig. 3) some plains possess all the karst characteristics described above, with the exception that they do not form closed depressions in the topographical sense required for genuine poljes. In such cases the term "semi-polje" is more suitable.

To the south of Koster, some small streams flowing on impervious beds of the Pretoria Group disappear in swamps when they enter the dolomite area. However, their dry beds can be followed into the dolomite area for several kilometers.

This large karst area is rather poor in accessible caves because, as a general rule, the watertable is shallow and most of the systems are water-logged.

From its flat character it may seem that this karst plateau has reached an advanced stage of evolution, but the study of its past development indicates that this is not really the case. On the dolomite from Krugersdorp to Zeerust are sinous ridge-like deposits of diamondiferous river gravels representing the remains of Tertiary (Du Toit, 1951; Cooks, 1968) paleo-river courses which now have often undergone reversal of topographic expression. These gravels were deposited on a mature surface after removal of most of the Karoo and before the present-day karst morphology developed. The present-day morphology has developed probably from the end of the Tertiary with disruption of the former N-S paleo-river system by incision and capture by the now dominant Limpopo river system.

Mayer (1973) postulates that the disruption of the former drainage pattern and lowering of the water-table in the dolomite of the Lichtenburg area was due to uplift during Late Tertiary to Early Pleistocene time.

\section{Escarpment Type}

When a new erosion cycle commencing from the Indian Ocean coast penetrates into the Plateau type, a rugged topography is developed with a dendritic network of valleys - the Escarpment type. It is especially characteristic in the Eastern Transvaal and between Pretoria and Krugersdorp.

This morphology does not differ markedly from that developed under similar conditions in nondolomitic terrains; in the Pretoria shales for instance. Karst morphology is not developed on a large scale, only lapies and occasionally collapse sinkholes can be observed. Caves, however, are abundant and often may belong to the system developed during the Plateau stage, now drained and intersected by the deepened valleys. Nevertheless, numerous other caves, sometimes still active, are situated deep in the valleys, at lower altitudes than the cave level associated with the eroded plateau. This indicates that caves are developing in the Escarpment Type topography without related erosion levels, or surface karst morphology (see section on erosion surface).

A general character of the Dolomite seems to be that a karst topography can really develop only on a fairly flat surface. If the area is rugged with steeper gradients, physical erosion controls the surface morphology. This is possibly due to the slow rate of dissolution of the dolomite, to the thunderstorm character of a great part of the rainfall and to the large number of fissures and joints that are choked and thus impede the rapid seepage necessary to prevent surface flow. In this way the Transvaal Karst contrasts strongly with other areas in the world characterized by more regular rainfalls and snow thawing on pure limestone, for instance in the Alps, where a karst morphology can develop even on steep slopes.

\section{Bushveld Type}

Between Thabazimbi and the Botswana border the Malmani Dolomite occupies relatively low altitude areas with very smoothed reliefs except isolated sugar-loaf hills (inselbergs). However, in the same area such hills are also developed on insoluble rocks like the Bushveld gabbro and are not typical of the Dolomite. Here again no major karst topography is developed. A few caves are known, some still active, but in general they are not common.

A further evolution of this morphology should lead to a mature karst-stage landform; but in fact erosion cycles are succeding so rapidly that the relief observed now will be rejuventated before the completion of the cycles. In this connection it may be noted that in the Eastern Transvaal the knickpoints of several cycles are relatively close together (Marker 1972), with the result that between two cycles even the Bushveld Type is not reached. 


\section{LEGEND}

SURFACE FEATURES

O Karst spring

$\cap$ Cliff cave

- Cenote-like sinkhole

More or less permanent stream

$\therefore$ Dry stream course

$f^{2}$ Escarpment of polje and semi-polje

\section{GEOLOGY}

Shale and quartzite (Pretoria Series) Dolomite

$\because$ Chert horizon in dolomite

Dyke
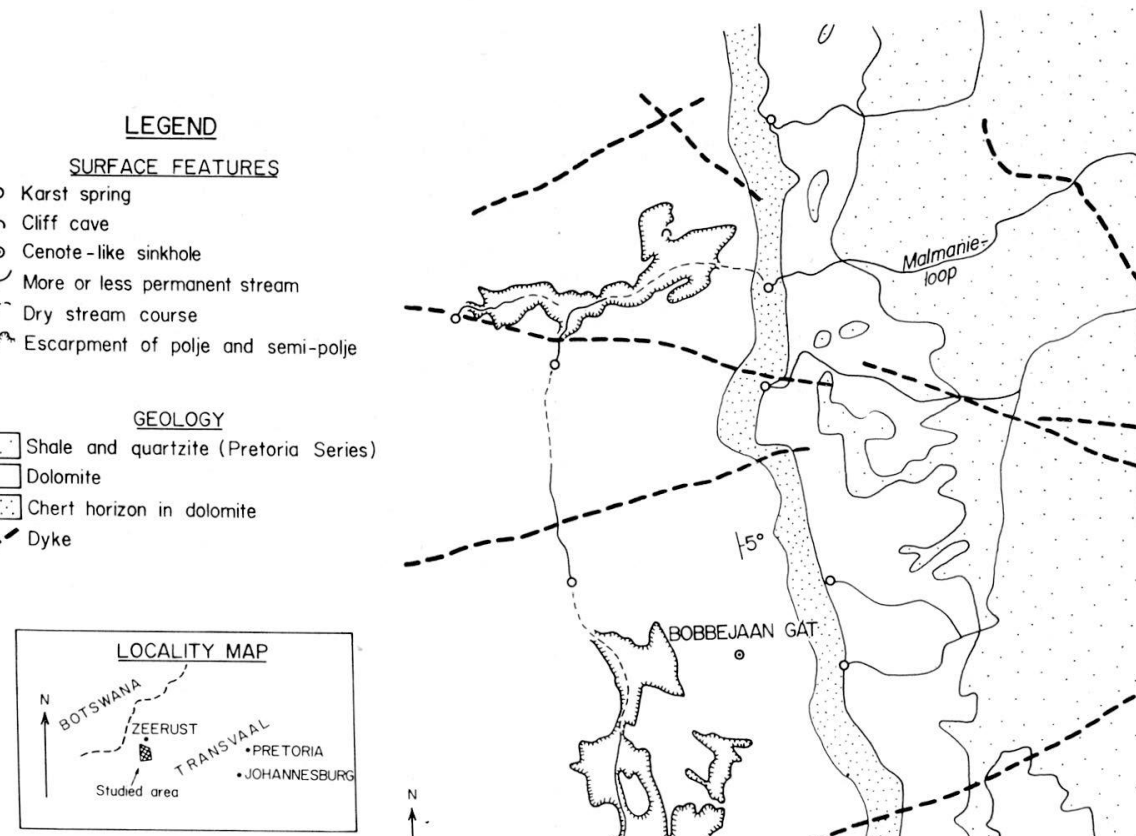

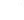




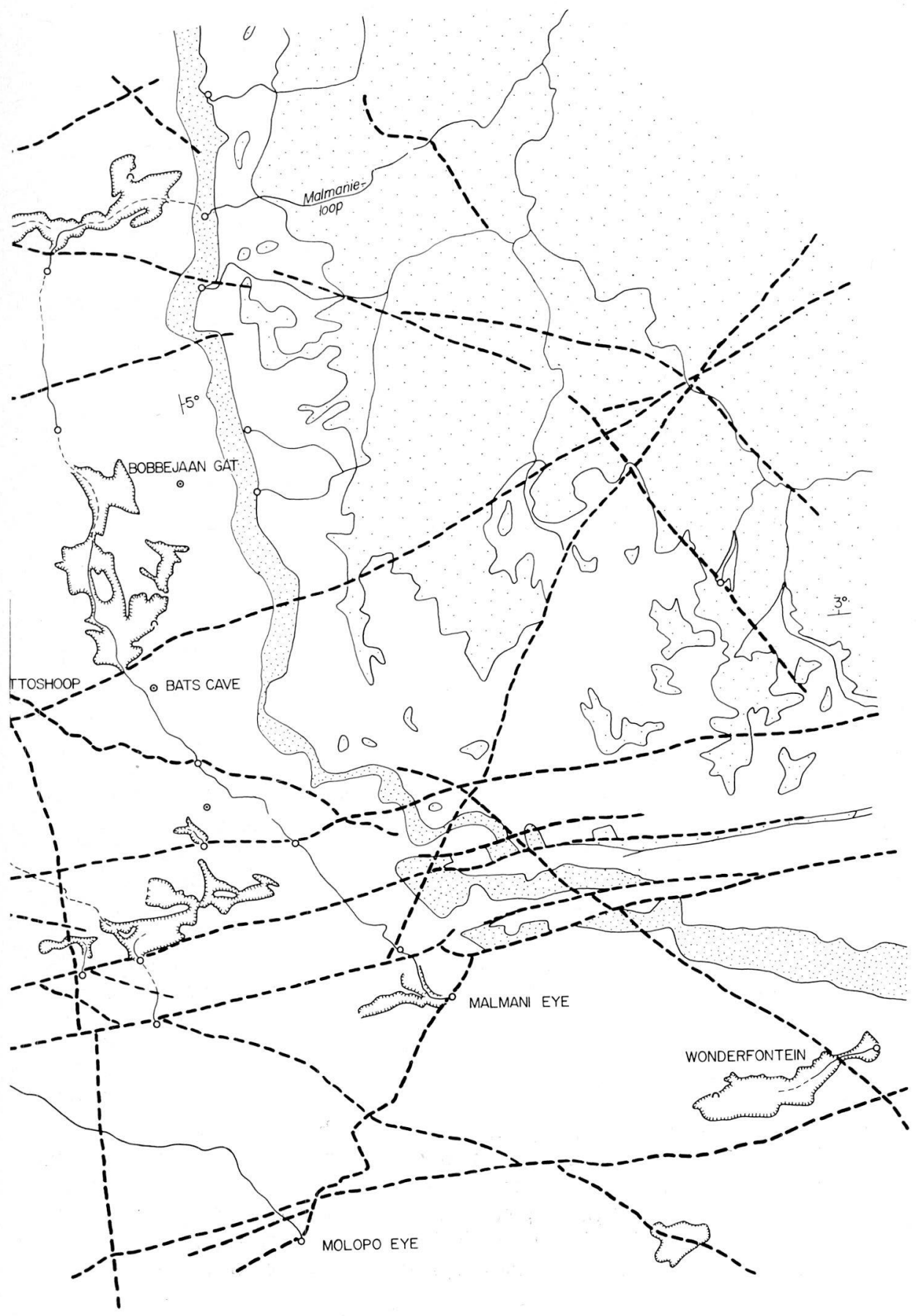




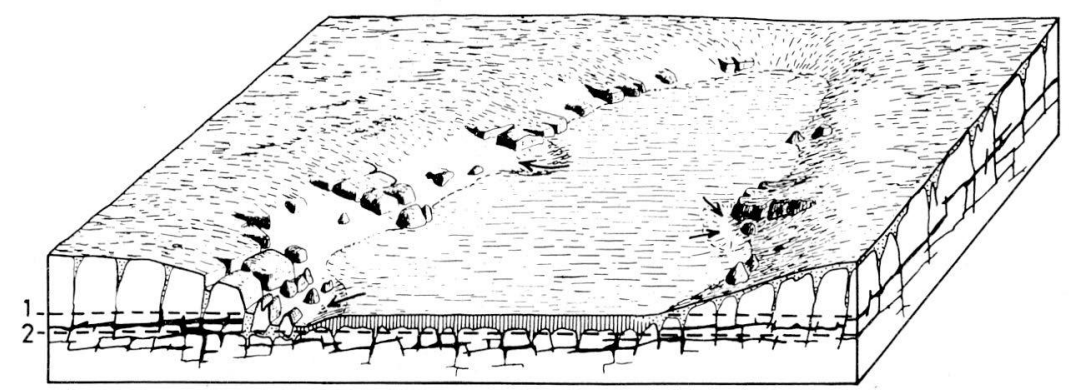

Fig. 4. Idealized diagram of polje from the Plateau type. Arrows indicate absorption points, polje fill is indicated by vertical hatching, water-table at maximum (1), and at minimum (2).

\section{Vaal River Type}

In the southern Transvaal, mainly in the Vaal river basin, the Plateau Type has been weakly incised by large valleys. As the relief is not prominent it is sometime difficult to establish a boundary with the Plateau Type; but, as a general rule, the karst morphology is not so well developed. Nevertheless disappearance of streams, and swampy plains having some character in common with the poljes of the Plateau Type are known along the valley of the Mooiriverloop, in the Far West Rand. Caves are common and include some of the largest systems.

\section{HYDROLOGY}

Most of the Dolomite ground-water is due to direct infiltration from rainfall. Nearly all the karst springs having a discharge of more than $0.05 \mathrm{~m}^{3} / \mathrm{sec}$ are located in the Dolomite areas of the South-Western Transvaal. Their main characteristic is that the discharge rate is very strongly buffered. Fluctuations of the discharge are not large and the timelag between a rainy season and the peak in the yield varies from 6 months to 2 years (Enslin, 1968). This is due partly to the thick cover of residual usually blanketing the Dolomite areas, through which the seepage is slow, to the large storage, as well as to the fact that numerous cavities under the watertable are filled with residuals.

Another characteristic is the weakness of the discharges compared to the size of the catchment areas. For instance the largest spring in the Transvaal, the "Oog van Schoonspruit" has an average discharge of $0.8 \mathrm{~m}^{3} / \mathrm{sec}$. for a catchment area of not less than $1000 \mathrm{~km}$; this is quite low if compared with the classic karst areas of Europe. The reason is the very high evapotranspiration combined with the relatively low rainfall. For instance in the Far West Rand, the infiltration has been calculated to be only $5 \%$ to $15 \%$ of the rainfall (Enslin and Kriel, 1967).

The Dolomite is almost everywhere criss-crossed by numerous diabase and syenite dykes. They are more or less impervious according to their weathering state and to their thickness, and they subdivide the Dolomite in numerous "compartments" isolated hydrologically from each other. This subdivision in compartments is a peculiar feature of the Transvaal karst. Some of the dykes act as ground-water barriers and many springs have their position controlled 
by them. This is typical in the Far West Rand and in the Ottoshoop area (Fig. 3 ). The other impervious rocks damming ground-water and controlling the position of the springs are the Black Reef Formation which underlies the Dolomite and the overlying Pretoria Group, some thick chert layers in the Dolomite (Fig. 3), and to a lesser extent thick quartz veins. In only a few cases are karst springs located where the water-table intersects the thalweg without lithologic reasons. The important springs do not lead to caves, as is commonly the case in other karst areas of the world.

The karst porosity has been measured accurately in the Far West Rand where several compartments have been de-watered by pumping by gold mines. It has been shown that it is a maximum near the water-table $(10 \%)$ and decreases rapidly to about $1 \% 100 \mathrm{~m}$ below (Enslin and Kriel, 1967). It is, however, difficult to know what is the real percentage of open cavities because many karst channels are in fact choked by a residual which is itself fairly porous.

\section{CAVES}

Caves are present everywhere, but are especially concentrated from Pretoria to the Far West Rand and in the Eastern Transvaal. Several types may be distinguished:

a. Fissure-caves. Provided they extend sufficiently, the caves develop as complicated mazes strongly controlled by jointing. It is probably the most common type in the Transvaal and the largest known cave-system in the country, Apocalypse pothole (extension $10.8 \mathrm{~km}$ ), belongs to this type (Fig. 5). Most of these caves, but not all, have a phreatic origin.

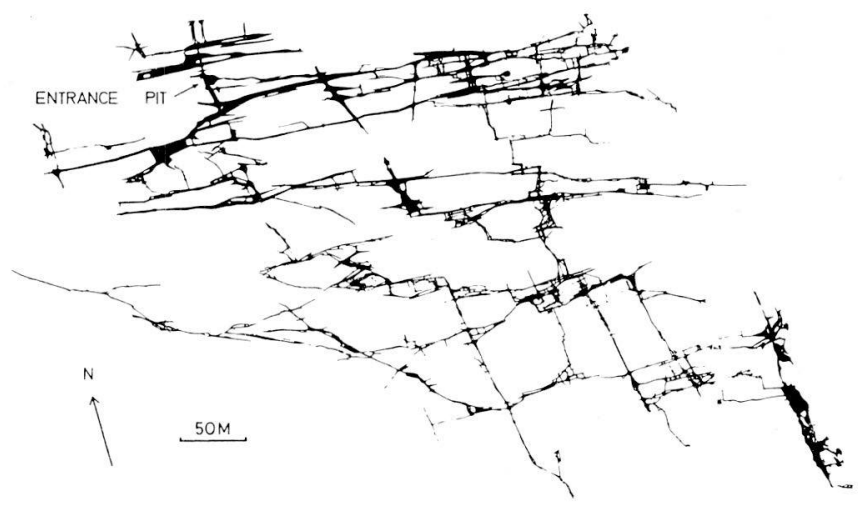

Fig. 5. Apocalypse pothole (after SASA Survey). 
It was observed in numerous caves that if the dolomite is intensely interbedded with chert layers, the carbonate component may be dissolved on both sides of the original joint without development of a cave passage; the chert and the very porous "wad" (see section on dissolution of dolomite) may remain undisturbed and therefore occupy the same volume as the unaltered dolomite. Transvaal caves as a general rule are peculiar in respect to the extreme decomposition found intact; walls and ceilings being heavily layered by dissolution products, giving on appearance of very doubtful stability. Very frequently it is observed that irregular cavities can develop by collapse and compaction of this residual (Fig 6).

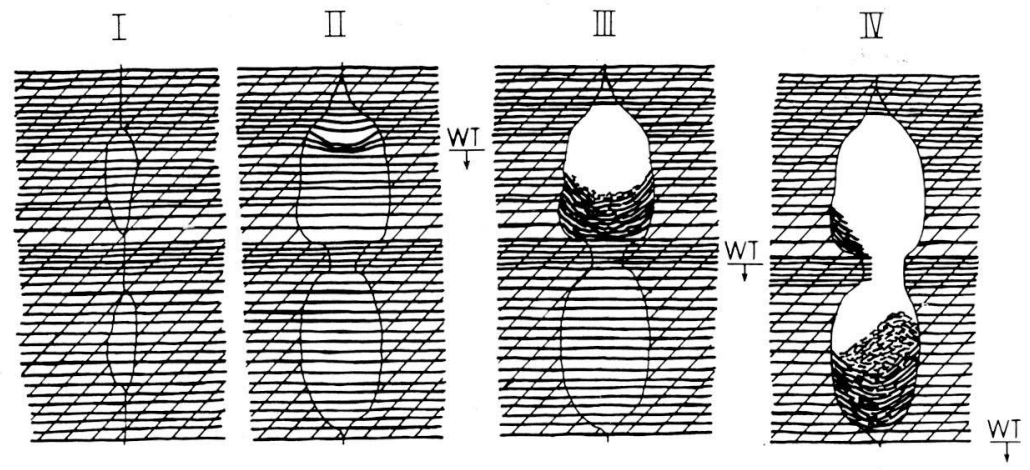

Fig. 6. Development of a cave in a very impure dolomite (idealized example from Chaos cave): Dissolution under the water-table does not lead to cavity development but when the water-table is withdrawn, passages are formed by compaction of the residual.

b. Simple pattern caves. Medium to large caves formed by only a few passages are not as common as the fissure caves. The cave of Sudwala, near Nelspruit in the Eastern Transvaal, belongs to this type.

c. Collapse cave. A large number of caves owe their actual pattern to upward collpase of the roof of original passages opened by dissolution (type a. or b.). They are generally simple caves with large irregular chambers in which big boulders are piled up. One of the most typical is the Wolkberg Cave, south of Pietersburg, Northern Transvaal, which has developed as a $800 \mathrm{~m}$-long passage almost entirely excavated by collapse.

The large number of collapse caves seems due to their antiquity and the mechanical properties of the dolomite which is more brittle than limestone. The great density of joints promotes collapse as soon as the cavity reaches a sufficient size.

Collapse may have occured below the water-table. This is likely the case for the "Wondergate" of the Western Transvaal, consisting now of large holes filled with water and sharing some features with the cenotes of Yucatan. However, in most cases collapse may have been triggered by withdrawal of water 


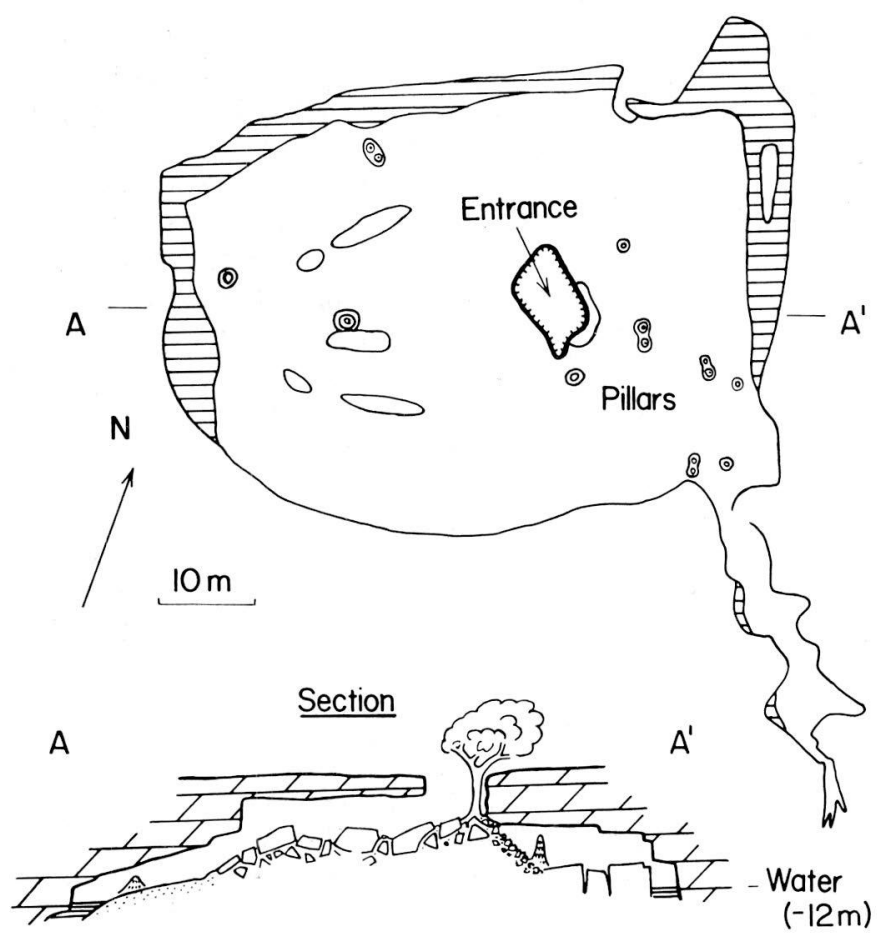

Fig. 7. Bats' cave, near Ottoshoop (after SASA Survey).

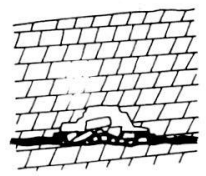

I

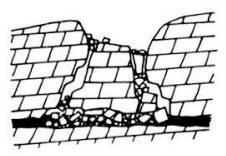

II

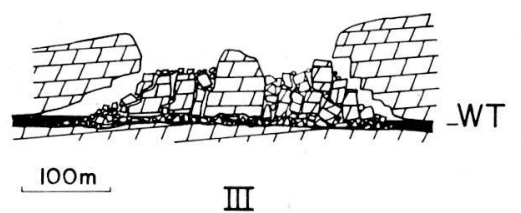

III

Fig. 8. Development of a "ring" cave by dissolution - collapse process (idealized example of Peppercorm - Ficus caves near Potgietersrus.

during a lowering of the water-table. The upward progression of a collapse chamber stops when the cavity is choked by blocks up to the roof, but if the lower part of the boulder pile is still water-logged, dissolution of blocks may produce more space for further upward collapse. This process leads eventually to the development of enormous bodies of dislocated dolomite surrounded by more or less perfect "ring caves" (Fig. 7 and 8). 
In the caves of the Transvaal, whatever their type, typical vadose features like keyhole passages are rare. Most of the channels leading to the water-table are vertical fissures filled with residual developed in situ. This general obstruction is due to the great abundance of impurities in the Dolomite. The fact that water seepage and dissolution are not impeded by the accumulation of the residual, as is often the case in other karst areas, is due to its fair permeability.

Horizontal cave entrances are common only in the Eastern Transvaal. In the Pretoria-Krugersdorp area, although deeply dissected by numerous valleys and gullies (Escarpment Type), most entrances are pit-like. The latter have formed by the collapse of the roof of chambers or by the development of a sink-hole through a residual filling (see section about recent sinkhole development). Horizontal passages intersecting the surface are generally obstructed.

It is also commonly observed that most of these entrances collect thunderstorm water from their immediate vicinity. These streams, which are active only a few hours a year, have a strong excavating effect on the residual filling which is transported and accumulates and compacts in the lower parts of the caves. This process of cleaning in the vadose zone is important because by opening choked, or half-choked passages, it makes many caves accessible to man.

The passages produced by the removal of residuals accumulated in vadose channels have a morphology similar to the phreatic passages and may sometime display a fissure maze pattern. This fact may be misleading in regional attempts to reconstruct the position of the paleo-water table by plotting "phreatic" caves unselectively on topographical profiles.

Many caves are exceedingly dry. This is due to the present-day climate, with a high evapotranspiration, and to slow rates of vadose seepage through thick mantles of residuum. In some caves, with large entrances or several entrances, there is an exchange of cold dry air flowing in during the night with warmer moisture-laden air rising from the cave, producing strong dehydration and oxidation. The relative humidity is generally less than $100 \%$ and evaporation takes place. This environment and the presence of $\mathrm{Mg}^{2}+$ is often favourable to the formation of aragonite and other rarer magnesium speleothems of dolomite, huntite, magnesite and hydromagnesite as "popcorn", fine drusy coatings and delicate needles. Aragonite is particularly common compared with other areas in the world. The strongly desiccating environment and lack of water has favoured the formation of soluble salts of chloride and nitrate, found preserved in very dry caves, and phosphates from bat guano. Although speleothems like stalactites, stalagmites, flowstone and rimpools are also frequently observed, they are generally not very extensively developed. For instance the volume of the formations observed in the vast system of the Apocalypse pothole is practically zero. In this cave, calcium carbonate is deposited in only a few dripping zones; in the other zones water is corroding the dolomite or other speleothems deposited at an earlier stage.

In most of the caves large formations are generally no longer active but are dead and more or less corroded. This re-solution effect has been attri- 
buted to rising of the water-table during wet periods (Marker, 1972). In some caves this may have been the correct explanation, especially in those near the actual watertable. But in most cases this process is unrealistic because corroded massive formations are common everywhere, irrespective of their relative altitude to the present water-table. Moreover the characteristic residual coating of clay covering the formations when they are brought into a quiet phreatic environment has been practically never observed.

It is probable that the seepage water dripping now in the caves or forming a capillary film on the walls is more frequently undersaturated in calcium carbonate than in the past, explaining the corrosion of the formations. From a theoretical point of view the actual rainfall regime (dry winter-rainy summer) seems more favourable to dissolution than to deposition because, after infiltration, summer rain water can only enter a colder or equal temperature environment. In cavities having a very poor air exchange with the outside atmosphere, the temperature will be regulated by rain water, as it is known that the temperature of Dolomite water is close to the temperature of summer rains and is $3-4^{\circ} \mathrm{C}$ more than the yearly average for air $\left(15\right.$ to $\left.18^{\circ} \mathrm{C}\right)$. However, for descending caves with large entrances, as are very frequent in the Transvaal, dripping water will enter a decidedly lower temperature environment. Therefore, calcium carbonate can be deposited only if the cooling effect is compensated by $\mathrm{CO}_{2}$ release and by evaporation.

On the other hand it is known that a climate with the rainy season in winter, offers good conditions for speleothem deposition. In the Transvaal it is possible that during Quaternary colder periods, the climatic belts shifted towards the north and that winter rains have (v. Zinderen-Bakker, 1976) been more abundant than now, inducing better conditions for speleothem development.

\section{THE DISSOLUTION PROCESS OF THE DOLOMITE}

The dissolution of dolomite can be divided into three distinct successive stages, corresponding to three zones of "rotten" dolomite, with in general, a total thickness of about $10 \mathrm{~cm}$. In exceptional cases dissolution products more than 1 metre thick are observed. Insitu dissolution products are almost ubiquitous and are a distinctive characteristic of Transvaal caves.

The stages correspond to compositional and textural changes the carbonate undergoes during its conversion to insoluble residual products.

\section{a. Incipient Stage of Dissolution}

At the first stage of dissolution the dolomite is characterized by a light brown discoloration and is mechnically weakened. Microscopically the dissolution is evident as intergranular staining of carbonate crystals by oxides of iron and manganese. Strongly stained dolomite, exhibits a very marked concentration of both $\mathrm{Fe} \& \mathrm{Mn}$ with a depletion of $\mathrm{Ca}$ and $\mathrm{Mg}$ at crystal boundaries. The 
dissolution is therefore very strongly selective along the crystal boundaries, and unlike typical dissolution of limestone.

However electron probe analysis of fresh dolomite shows there is no primary variation in composition across crystal boundaries to enhance selective solution and that the composition of the dolomite at this scale is homogeneous. For the dolomite interfacial energy of the crystal lattice is probably quite high, inducing a higher solubility.

\section{b. Arenaceous Stage of Dissolution}

Dolomite at this further stage of dissolution is characteristically granular. It is a typically brown, or speckled white and brown, "arenaceous" material that is readily crushed or naturally eroded to a dolomite sand. Microscopically, carbonate crystals show a heavy oxide coating. X-ray examination reveals dolomite and quartz to be present, with a high background due to noncrystalline oxides of iron and manganese. No calcite or aragonite was found in a large number of arenaceous dolomite samples, collected in the deepter parts of caves where no $\mathrm{CaCO}_{3}$ is precipitated, which suggests that during dissolution $\mathrm{Ca}^{2}+$ and $\mathrm{Mg}^{2}+$ ions enter solution at comparable rates, that is, solution is congruent. This conclusion is further supported by a quantative analysis for $\mathrm{Ca}$ and $\mathrm{Mg}$ of fresh and weathered dolomite, revealing that the $\mathrm{Ca} /$ $\mathrm{Mg}$ ratio remains unchanged during dissolution.

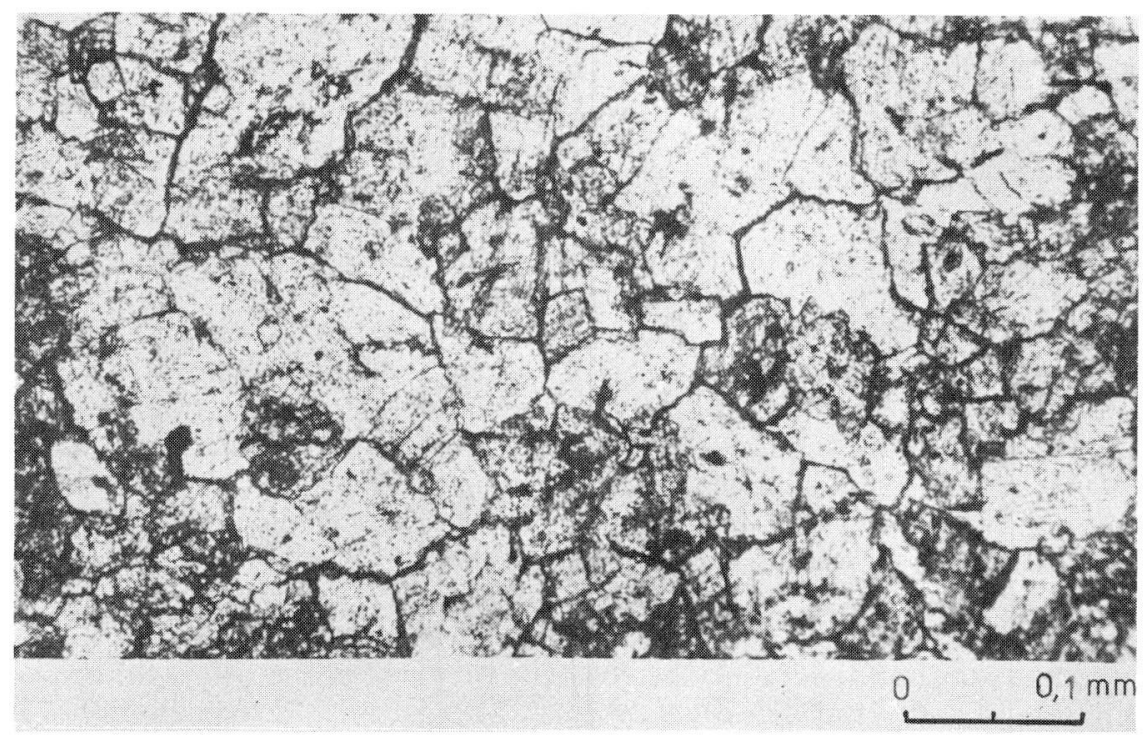

Fig. 9. Dissolution of dolomite; The incipient stage, microphotograph showing oxide coating of the dolomite crystals. 
As the carbonate is progressively removed, secondary porosity increases and insoluble oxides of $\mathrm{Si}, \mathrm{Fe}, \mathrm{Mn}$ accumulate pseudomorphing the original crystalline fabric.

Dolomite showing "arenaceous" weathering is very commonly observed.

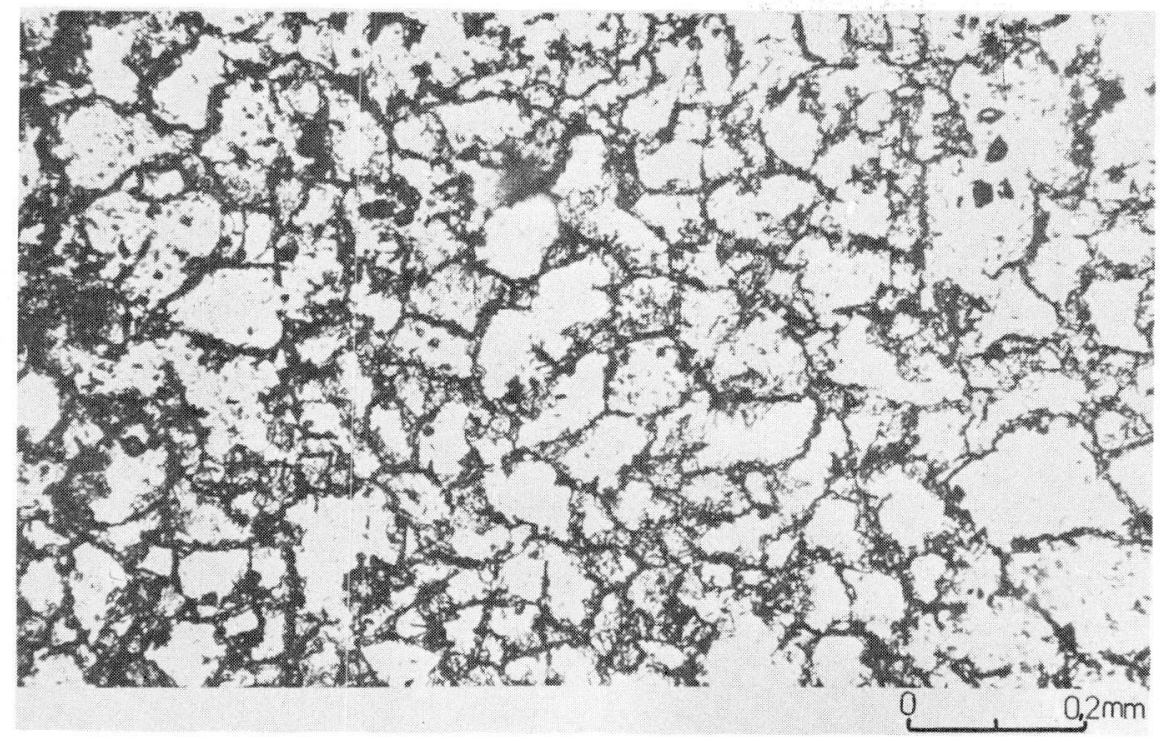

Fig. 10a. Dissolution of dolomite: The cellular stage, microphotograph showing the sponge-like fabric of oxides pseudomorphing the original crystallinity of the dolomite. Compare with Fig. 9.

\section{c. Cellular Sage of Dissolution}

The final stages of dissolution is only preserved in suitably protected environments and can be studied only undisturbed in caves. At this stage all carbonate is removed and a cellular fabric, composed of iron and manganese oxides and hydroxides and silica, pseudomorphing the original crystalline structure remains (Fig 9 and 10). This unusual solution product has been termed "wad" by South African geologists. "Wad" develops in a cave or in the soil, not on exposed dolomite. Although dissolution occurs primarily below the water-table during cave excavation, it is probable that the action of vadose water may be partly responsible for this cellular stage. This material is very fragile, extremely compressible and has a natural density in the order of $0.4 \mathrm{~g} / \mathrm{cc}$. In the natural state $20 \%$ or more of the mass is due to water. The void space may amount to over $90 \%$ of the material.

It is probable that there is essentially little exchange or concentration of the oxides during carbonate dissolution, and hence the composition of this 


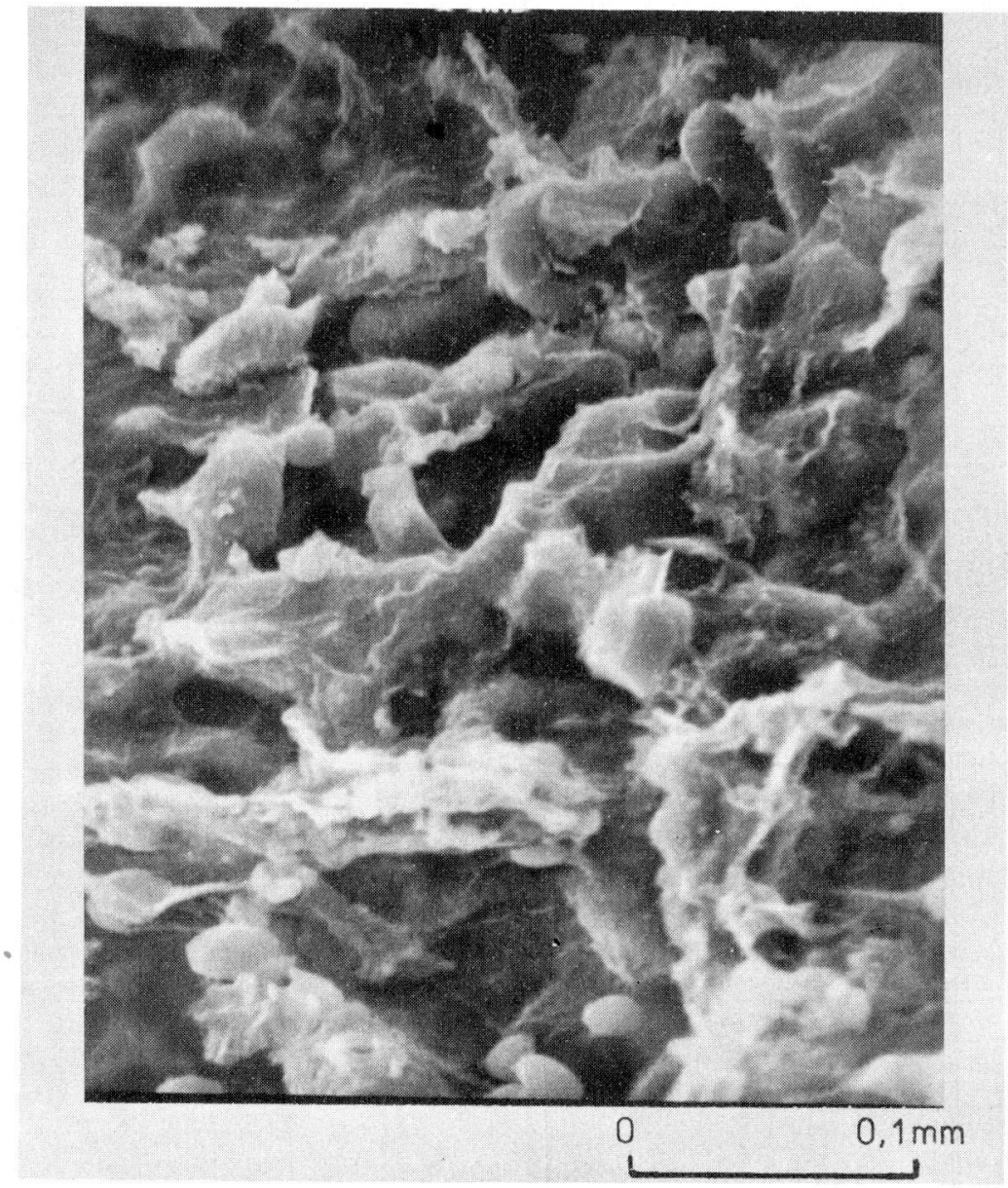

Fig. 10b. Dissolution of dolomite. The cellular stage, electron microphotograph showing the amorphous cellular structure of the solution residual. Microcrystalline quartz and rounded "beads", probably amorphous oxides adhere to the walls.

dissolution residual, if not unduly modified by secondary processes, reflects the original $\mathrm{Fe}, \mathrm{Mn}, \mathrm{SiO}_{2}$ content of the parent rock.

Nevertheless in some caves iron and manganese oxides have been obviously leached out and redeposited elsewhere. For instance mobility of manganese is especially obvious in the cave of West Driefontein where manganese speleothems as stalactite, stalagmite and flow coating are frequent. These formation are soft gel-like and composed of non-crystalline black oxides. 


\section{CHEMISTRY OF DOLOMITE GROUND-WATER}

An interesting aspect of the Dolomite ground-water is its chemistry. It is known (Bond, 1946) that the $\mathrm{Ca} / \mathrm{Mg}$ ratio is higher in the Dolomite than in the ground-water.

According to these data it has been calculated that for the Fountains Spring, near Pretoria, the yearly deficit in calcium carbonate is close to 200 tons, for an average discharge of $0.27 \mathrm{~m}^{3} / \mathrm{sec}$ and a total removal of 1570 tons of soluble matter (Martini, 1973). As it has been stated previously that the dissolution of the Dolomite is congruent, this deficit represents the amount of calcium carbonate deposited as cave formations.

\section{DATING, CAVE LOCATION AND EROSION SURFACES}

As a general rule, dating of a cave development is difficult. Suitable Cainozoic fossils, and datable sedimentary or volcanic deposits are virtually absent in the Transvaal. Nevertheless there are several sites of palaeontological significance (notably Sterkfontein, Swartkrans, Kromdraai and Makapansgat) that contain Australopithecine and associated mammal fauna. These fossils are found in a breccia filling introduced from the surface into caves already dry for a certain time (Brain, 1958) and consequently indicate a minimum age for the cave development. It is inferred by comparison with the well-dated East African sites like Olduvai, that the oldest Australopithecine fauna (Sterkfontein and Makapan) are at least 1.75 m.y. old, although they may be even older, possibly between 2.0 and $2,5 \mathrm{~m}$.y. Therefore compared to many karst areas in the world the Transvaal Karst is old, and the period of active development was probably during the Pliocene.

Various workers (King, 1963; Marker and Moon, 1969; Marker, 1972 and Partridge, 1973) have attempted to relate cave altitude with the level of coeval erosion surface remnants of the South African landscape, and thus determine at least the relative age of these systems.

Partridge (1973) has calculated from rates of erosion, related to cyclic uplift the data of cave opening at Makapansgat to be 3.67 m.y., Sterkfontein 3.26 m.y. and Swartkrans as 2.57 m.y. It is extremely doubtful however that the draining of a phreatic system, its opening by erosion and subsequent filling by terrestrial deposits can be dated with any accuracy by considering the time of arrival of an erosion cycle from the Indian Ocean coast, a distance varying from 300 to $1000 \mathrm{~km}$ according to the stream considered. Moreover draining of a phreatic cave does not necessarily occur when its level is intersected by adjacent valley incision, but when the particular water barrier is incised: for example the "eye" of Turffontein in the Far West Rand, due to a dyke, controls the water-table for more than $25 \mathrm{~km}$ away.

In the Eastern Transvaal, Marker and Moon (1969) and Marker (1972) have produced a diagram showing simple relations between cave location and erosion levels nearly horizontal over very large areas. The validity of a 
great part of the data is questionable; many caves are too small to be diagnostic, others are vadose or due to upward collapse from a phreatic level situated at a lower but unknown altitude. The cave of the Wolkberg is indicated as a 3-level cave, whereas it is in fact a one-level cave strongly modified by collapse. Moreover the altitude of certain caves (e.g. Ceylon) is not correct. Therefore if only reliable data are considered, the correlation of caves with erosion surfaces is not obvious in this part of the Transvaal.

The recent exploration and survey by S.A.S.A.* of extensive cave systems in the Far West Rand has made possible the accurate location of several contemporaneous palaeowater-tables (publication in preparation). This study shows with clarity that the water-tables were not controlled by nearly flat peneplains but by dykes intersecting a thalweg with gradients comparable to present (about $3 \mathrm{~m} / \mathrm{km}$ ).

However, it is probable that in the past the water-table was controlled by several factors among which erosion cycles, not necessarily evolved to peneplains, may be included. But this factor can be determined only by studies more detailed than those generally attempted up to now.

\section{RECENT SINKHOLE DEVELOPMENT}

As already mentioned large portions of the Karst area, particularly the Plateau type surface, are characterized by the development of a thick blanket of residual solution debris. The stability of the mantle has been adversely affected by mans' utilization of the environment.

De-watering of dolomitic compartments in the Far West Rand by the gold mines has resulted in the development of numerous large-scale collapse sinkholes and extensive ground subsidence. In December 1962, 29 lives were lost when a crusher plant at the West Driefontein Gold Mine disappeared without warning into a sinkhole 30 metres deep and 55 metres in diameter. In the same area a family of 5 lost their lives when their house collapsed into a sinkhole of similar dimensions. Three other homes fell into the same hole, but the residents escaped uninjured (Foose, 1968). In highly urbanized areas immediately south of Pretoria similar problems of stability have occured; not, however, due to the withdrawal of ground-water, but due to other maninduced factors, such as concentration of surface water from sealed surfaces, or inadequate storm-water drainage or burst pipes.

\section{The residual mantle}

Due to a complex history of weathering (as indicated by multiple Karst periods) the present-day residual mantle is derived from: (1) recent dolomitic dissolution; (2) the weathering of older pre-existing and incorporated Karst

* South African Spelaeological Association. 
regoliths and, (3) from rock formations (sedimentary and igneous) younger than the Dolomite. Shales of Karoo or Pretoria Group age are frequently found, with siliceous residuals from ancient paleokarst. Decomposed igneous rocks of a wide range of ages occur as dykes or sills. Further the incorporation of Quaternary sediments (of both fluvial and aeolian genesis) and the development of very thick mantles since late Tertiary time has resulted in the development of a highly variable and complex overburden.

This inordinately thick residual blanket is best observed on the Plateau and Vaal River Type morphologic surfaces, particularly in the Far West Rand. More rugged karst morphologies, such as the Escarpment type are characterized by partially denuded landforms.

\section{Sinkholes and Subsidences}

Sinkholes and subsidence structures are syngenetic with the accumulation and development of the insoluble residual blanket and have occured naturally, but infrequently throughout the Recent period.

Two types of sinkhole are recognized (Jennings et al., 1965): (1) compaction sinkhole and, (2) collapse sinkhole.

The compaction sinkhole is a gradual subsidence forming an enclosed depression in the ground surface and is referred to by Jennings as a "caving subsidence". A collapse sinkhole forms by a sudden collapse and is usually deep with vertical sides. Both kinds of sinkhole have become a frequent phenomenon in the Far West Rand due to dewatering by the gold mines.

The withdrawal of interstitial fluids in a relatively open chert rubble fabric, produces considerable consolidation and settlement of the residual cover. Where the karst subsurface is relatively even, large areas have subsided without damage to buildings, apart from those at the margins of such features. Upon a highly variable karst topography or cavernous bedrock, differential subsidence of the overlying debris has led to catastrophic failure at the surface, usually with the formation of conical or shaft-like collapse structures within thick sequences of residuum. The catastrophic sinkholes form by the collapse of a pre-existing or induced cavity within the residuum, or a void open to the introduction of residuum, within the bedrock. The propagation of such a cavity to the surface occurs by a combination of a number of processes. Important are "roofing" processes within the residuum due to changes of moisture content, seepage and piping mechanisms. These changes may be natural, for example seasonal variations in moisture, or produced by the external influence of man. (Jennings et al., 1965) by "spalling" of rubble (Foose, 1968) or "ravelling" (Sowers, 1975) and lead to the formation of collapse sinkholes.

In urban areas a large number of sinkholes can be generally ascribed to "piping" failure. Dry winters and in contrast frequent thunderstorms in summer, producing very large concentrations of runoff are an important factor.

The process of "piping" is particularly effective in a poorly consolidated, 
heterogeneous debris composed of chert rubble and soil, or against bedrock subsurfaces where the flow of infiltrating water is concentrated and the erosive efficiency is therefore far greater. In chert rubble the open fabric provides the necessary permeability. Percolating water transports the clay and silt-sized fraction (the matrix) internally, leading to progressive compaction or collapse of unsupported material. The descent of materials into fissures or cavities in a dolomite bedrock leads to the formation of voids within the residual mantle that with time are enlarged and migrate upwards. The surface materials become weakened with saturation and collapse forming a characteristic sinkhole.

Sinkholes form generally in thick sequences of residuum or where the thickness is highly variable. Some recent sinkholes are, however, found among outcropping dolomite usually the result of fissures or small caverns near the surface being exhumed by stormwater. These features are usually small.

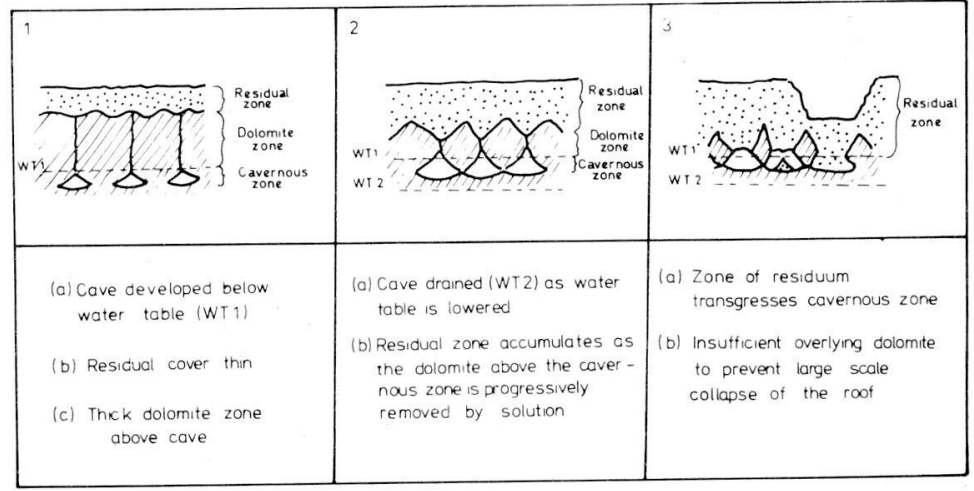

Fig. 11. The development of sinkholes when the residual zone reaches the water-table.

Paleosinkholes filled with Quaternary sediments have been detected by geophysical surveys and drilling in the Far West Rand (Kleywegt and Enslin, 1973). In some cases such features have been reactivated by dewatering.

A very small percentage of recent sinkholes are found to lead to caves, since generally they occur almost entirely within the residual zone. Secondly any underlying cavity that may have existed within the bedrock has now been entirely choked by the collapsed debris.

It is apparent that with a very extensive development of residuum the level at which earlier cave systems developed has been exposed to mechanical breakdown (i.e. collpase) and is being incorporated into the developing mantle of rubble. The present-day water-table is also often within the residuum and 
above coherent bedrock, with the result the stability of the mantle is adversely affected by de-watering. In these areas chemical solution has progressed more rapidly than the lowering of the land surface by physical erosion.

An important consequence of this observation is that at this stage of karst evolution conditions become particularly favourable for the development of sinkholes. This model of sinkhole formation is illustrated in Fig. 11.

\section{South African Spelaeological Association and Geological Survey}

\section{SUMMARY}

The Transvaal Karst is a world important example of a Karst developed on a very old dolomite. Its unique character is due to the composition of the rock and history of development. The dissolution of the dolomite is interesting and has an important effect on the character of the caves developed. The caves preserved in this area include the longest known in South Africa and are perhaps among the largest dolomite systems known in the world. They are very old and in some cases contain important palaeontological deposits (Australopithecine fauna). The caves to various degrees are in a state of de-generation, having been exposed for a very long period above the water-table. For the greater part of the Karst area, aggressive vadose waters, and long exposure has resulted in the accumulation of a thick covering of residual material. The plateau-like geomorphology and low rainfalls has prevented physical erosion and significant removal of this debris from the land surface.

The caves themselves are often characterized by collapse and in general lack of formations. Massive calcite formation in the caves is usually partly or nearly completely redissolved and are relics of past colder climatic periods with winter rains. Formations active now are small, usually delicate and often due directly to evaporation.

The heavy mantle of residual debris preserved under some of the more ancient of South African landsurface relics (the African Surface) poses a serious economic problem of stability, with mans' utilization of the environment. A greater understanding of the Karst, its evolution and properties is thus of considerable practical importance.

\section{RÉSUMÉ}

Le karst du Transvaal se développe dans une dolomie précambrienne riche en silice, fer et en manganèse. Cette composition particulière est en grand partie responsable du caractère inhabituel que présente ce karst: grand développement de résidus poreux, lenteur de l'écoulement des eaux souterraines et apparition de dolines par suite de l'activité humaine. La morphologie karstique est peu apparente en surface, sauf sur les plateaux. Par contre, les grottes sont nombreuses et montrent souvent des réseaux compliqués. Sont aussi typiques des grottes d'effondrement pouvant atteindre de grandes dimensions et dues à l'action simultanée de la subsidence et de la dissolution. Divers autres aspects du karst sont décrits.

\section{ACKNOWLEDGEMENT}

The authors would like to thank the Director of the Geological Survey, Dr. J. F. Enslin and Dr. L. E. Kent for their constructive criticism and reading of the manuscript and $\mathrm{Mr}$. C. Wallace for his invaluable assistance with the electron probe work. Members of the South African Spelaeological Association (Transvaal Section) with whom the authors have spent many hours of exploration, surveying and collection of samples, are gratefully acknowledged. 


\section{REFERENCES}

BEZUIDENHOUT, C. A. and ENSLIN J. E. (1969): Surface subsidence and Sinkholes in the dolomite area of the Far West Rand, Transvaal, Republic of South Africa. Int. Symp. on Land Subsidence, Tokyo, sept. 1969, 9 p.

BOND, G. W. (1946). A geochemical survey of the underground water supplies of the Union of South Africa. Geol. Survey, Mem. 41, 208 p.

BRAIN, C. K. (1958). The Transvaal ape-man-bearing cave deposits. Transvaal Museum, Mem. $11,131 \mathrm{p}$.

BRINK, A. B. A. and PARTRIDGE, T. C. (1965). Transvaal Karst: some consideration of development and morphology, with special reference to sinkholes and subsidences on the Far West Rand. South African Geogr. J., 47, 11-34.

BREDENKAMP, D. B. and VOGEL, J. C. (1970). Study of a dolomitic aquifer with carbon-14 and tritium in isotope hydrology. 1970, Int. Atomic Energy Agency, Vienna, 349-372.

BUTTON, A. (1973). The stratigraphic history of the Malmani Dolomite in the eastern and north-eastern Transvaal. Trans. Geol. Soc. South Africa, 76, 229-247.

COOKS, J. (1968). Paleodreineringslyne in die Wes-Transvaalse karstgebied. South African geogr. J., 50, 101-109.

DOUGLAS, I. (1965). Calcium and magnesium in karst waters. Helictite, 3, 23-36.

DU TOIT, A. L. (1951). The diamondiferous gravels of Lichtenburg. Geol. Surv. Mem. 44, 36 p.

ENSLIN, J. F. (1968). Dolomitic water supplies in the Transvaal, Republic of South Africa. Int. Ass. Hydrogeologists Mem. Congr. Istanbul 1967, 476-433.

ENSLIN, J. F. and KRIEL, J. P. (1967). The assessment and possible future uses of the dolomitic ground water resources of the Far West Rand, Transvaal, South Africa. Water for peace conference, Washington, 1967.

FOOSE, R. M. (1968). Surface subsidence and collapse caused by ground-water withdrawal in in carbonate rock area. Rep. 23rd int. geol. Congr. 12, 155-166.

JENNINGS, J. E., BRINK, A. B. A., LOUW, A. and GOWAN, G. D. (1965). Sinkholes and subsidences in the Transvaal Dolomite of South Africa. Sixth Int. Conf. on Soil Mechanics and Foundation Engineering, Montreal, September 1965.

JENNINGS, J. N. (1971). Karst. M.I.T. Press, Cambridge, Massachusetts and London, 252 p.

KING, L. C. (1963). South African scenery. 3rd Ed, revised, Oliver and Boyd, Edinburgh and London, $308 \mathrm{p}$.

(1967). Morphology of the earth. 2nd Ed., Oliver and Boyd, Edinburgh and London, $726 \mathrm{p}$.

KLEYWEGT, R. J. and ENSLIN, J. F. (1973). The application of the gravity method to the problem of ground settlement and sinkhole formation in dolomite of the Far West Rand, South Africa. Proc. Int. Assoc. Eng. Geol. Symposium: Sinkholes and Subsidence.

KRIEGE, J. (1948). Boorgattemperature in die Transvaal en die Oranje Vrystaat. Geol. Survey Bull. 18, 1-24.

MARKER, M. E. (1972). Karst landform analysis as evidence for climatic change in the Transvaal. South African geogr. J., 54, 152-162.

MARKER, M. E. and MOON, B. P. (1969). Cave levels and erosion surfaces in the Transvaal, South Africa. Ibidem, 51, 106-113.

MARTINI, J. (1973). Chemical composition of spring water and evolution of Transvaal Karst. Bull. South African speleo. Ass., 1972, 11-14.

- (1975). Palaeokarst, diagenetic porosity and palaeography as major mineralization control in Transvaal dolomite south of Zeerust. South African J. Sc., 71, 276.

MAYER, J. J. (1973). Morphotectonic development of the Harts River Valley in relation to the Griqualand - Transvaal Axis and the Vaal and Molopo Rivers. Trans. Geol. Soc. South Africa Vol. 76 part 3, p. 183-193.

PARTRIDGE, T. C. (1973). Geomorphological dating of cave opening at Makapansgat, Sterkfontein, Swartkrans and Taung. Nature, 246, 75-79.

PARTRIDGE, T. C., TALMA, A. S. and VOGEL, J. C. (1974). Isotopic content of some Transvaal spelaeothems and their palaeoclimatic significance. South African J. of Sc. Vol. 70, 135-140. 
SOWERS, G. F. (1975). Failures in limestone in humid substropics. Jour. Geotech. Eng. Div. Proc. Am. Soc. of Civil Engineers, Vol. 101, 521-787.

TRUSWELL, J. F. and ERIKSSON, K. A. (1975). A paleoenvironmental interpretation of the early proterozoic Malmani Dolomite from Zwartkops, South Africa. Precambrian Research, 2, 277, 303.

WEATHER BUREAU, (1952). Climate of South Africa, part 2, Rainfall Statistics. Gov. Printer, Pretoria, 187 p.

v. ZINDEREN-BAKKER, E. M. (1976). The evolution of late-quaternary palaeoclimates of Southern Africa. Palaeo-ecology of Africa, vol. IX, A. A. Balkema, Cape Town. 